\title{
Enhancing Safety and Reliability of Electric Power Supply to Consumers through Safe Electricity Networks of up to $1 \mathrm{kV}$
}

\author{
Yurii Shelekh ${ }^{a,},{ }^{*}$ Myroslav Sabat ${ }^{a}$, Vladyslav Lysiak $^{a}$, Lidija Parashchuk $^{b}$ \\ ${ }^{a}$ Lviv Polytechnic National University, 12 Stepan Bandera St., Lviv, 79013, Ukraine \\ ${ }^{b}$ Hetman Petro Sahaidachnyi National Army Academy, 32 Heroes of Maidan St., Lviv, 79026, Ukraine
}

Received: October 08, 2021. Revised: October 26, 2021. Accepted: November 02, 2021.

(C) 2021 The Authors. Published by Lviv Polytechnic National University.

\begin{abstract}
The study presents an electric network that allows both increasing the level of electrical safety and eliminating one-phase damage to the electrical network without switching off the consumer's electric energy. The application of the network does not require significant investments. The technical feasibility of implementing an electrical installation with voltage values in the emergency mode on the leading parts, which does not exceed the permissible values for normal mode, is demonstrated. An additional advantage of the proposed technical solution is the immutability of the voltage at the customer's outputs, which allows it to operate normally also in the emergency mode of the electrical installation.
\end{abstract}

Keywords: electric network; high voltage; power supply; differential current devices.

\section{Introduction}

Reliability and safety of power supply delivered to consumers is subject to relevant regulations, state building regulations, and standards, etc. Over the last 25 years, Ukraine has increasingly benefited from foreign experience in this area. However, most of innovations, if analyzed, involve the replacement of worn-out and outdated equipment with a more advanced one. A change in the principles of operation occurs rarely.

The Constitution of Ukraine proclaims: "An individual, his life and health, honour and dignity, inviolability and security shall be recognised in Ukraine as the highest social value. Affirming and ensuring human rights and freedoms shall be the main duty of the State" (Article 3).

Every citizen of the country is a consumer of electric energy and deals with electrical installations in everyday life, in production, in public places. "The State shall protect the rights of consumers, exercise control over the quality and safety of products and all types of services" (Article 42). And then: "Everyone shall have the right to proper, safe, and healthy labour conditions" (Article 43) and "Everyone shall have the right to health protection, medical care and medical insurance" (Article 49).

Human has to be protected from electric shock. Their rights as a consumer of electric power are defined by the Law of Ukraine "On Protection of Consumer Rights", which, in particular, notes: "Consumers shall have the right to state protection of their rights; compensation for loss as well as damage caused by goods (services) threatening the life and human health in cases provided for by law" (Article 3). Article 4.1 confirms that "the state shall provide citizens with the protection of their interests as consumers, provide an opportunity for obtaining the knowledge and skills necessary for making independent decisions when using goods (services) according to their needs".

\section{Presentation of main material}

Operating practices have shown a high level of reliable and accurate functioning of protective circuit breakers (PCBs) in the event of human coming in contact with current-carrying parts or damaged parts of electrical installations. Their usage conditions are governed by the practice guidelines [1], [2]. Until the 90's, the state of fatal

\footnotetext{
* Corresponding author. Email address: yurii.1.shelekh@lpnu.ua
}

This paper should be cited as: Y. Shelekh, M. Sabat, V. Lysiak, L. Parashchuk. Enhancing safety and reliability of electric power supply to consumers through safe electricity networks of up to $1 \mathrm{kV}$. Energy Engineering and Control Systems, 2021, Vol. 7, No. 2, pp. 97 - 102. https://doi.org/10.23939/jeecs2021.02.097 
electrical injuries in Ukraine, as repeatedly noted, that is, before the implementation of regulations on the mandatory use of the PCB, was about 30 persons per one million of the population [3]. After alterations have been made in the regulations concerning installing PCBs, the statistics on fatal electrical injuries has barely changed and is now and will be in future nearly 30 persons per one million population and even more than 2000 persons per year, as reported by certain sources [4].

The leading companies mainly produce electromechanical PCBs and in low quantities - the electronic ones [5], [6]. However, the latter are allowed to be used as optional to electromechanical PCBs according to regulatory documents. The peculiarity of the design of the modern PCB is that it contains a special material for a current transformer core whose magnetic characteristics are strictly regulated. Its magnetic-latching relay is constructed using a highly precision technology. Furthermore, the PCB incorporates a highly reliable mechanical trip and a spring mechanism with the position indicator of terminals. It is worth noting that the actuation time of the PCB at leak current, equal to the set point, is approximately $0.3 \mathrm{~s}$ whereas a response time will be $0.04 \mathrm{~s}$ provided that the actuation set point is surpassed five times. That is, the trip current of PCB for the actuation time in two full periods for the set point of $30 \mathrm{~mA}$ amounts to $150 \mathrm{~mA}$.

The leading firms that manufacture PCBs have achieved considerable success, first and foremost, in increased operational reliability. The level of manufacturing technology, professional training of personnel, control and testing methods, design excellence, generally, makes it possible to ensure increasingly strict requirements for PCB specifications.

In our opinion, the problem lies in the content of certain regulatory requirements. For example, on the application of PCBs the following is stated in clause 1.7.1 [1]: "This section of Rules applies to electrical installations of alternating and direct current, intended for the production, conversion, transformation, transmission and distribution of electricity of new construction and to those buildings that are being reconstructed or technically re-equipped". As for existing electrical installations, it is stated that "The requirements of this section may also apply to existing electrical installations in order to improve their electrical safety". That is, the use of PCBs is mandatory in new buildings, and in existing electrical installations, this issue is left to the discretion of the electricity consumer, who chooses the best option based only on a comparison of the cost of protective equipment.

Unfortunately, the current rules quite often contain pure recommendations. Accordingly, their dual interpretation leads to misunderstandings between educational institutions, design organizations, utilities, and supervisory bodies. In foreign countries, the issue of installing the PCB was raised clearly and unambiguously - PCB installation must be everywhere. The result of this approach can be evidently traced through the example of Switzerland (Fig. 1).

Ways to improve electrical safety were outlined in [7], [8]. The typical household electrical networks do not guarantee the necessary level of electrical safety during their operation. The principles of the synthesis of electrical networks with the increased level of electrical safety are proposed there, and criterial requirements for the parameters of such networks are formulated. In addition to the theoretical ways of correcting the values of permissible actions on the human body, also considered are the practical ways to increase the level of electrical safety. Except for theoretically tuning the values of permissible effects on the human body, the ways to enhance electrical safety were also considered in practice. The schematic solution shown in Fig. 2 requires a particular attention [9].

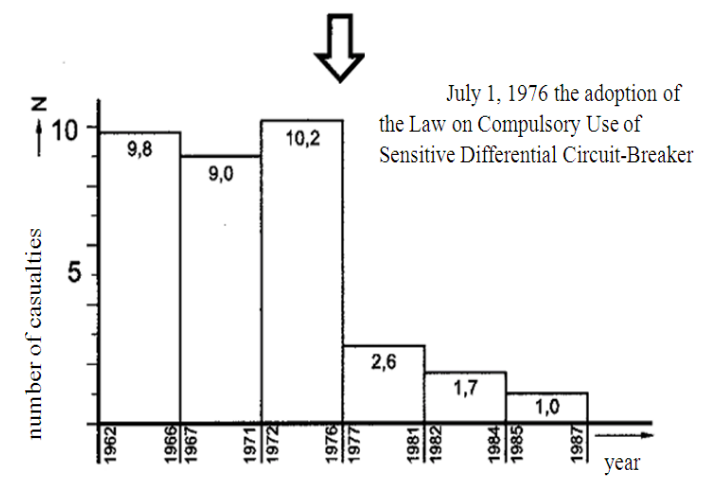

Fig.1. Diagram capturing a change in the number of fatalities in Switzerland before and after the adoption of the law on PCBs Compulsory Use. 
The advantage of this method of high-speed shunting is to eliminate the effects of the factors of human lesion, and the disadvantage lies in the difficulties during the selective determination of the fact of the human touch to the current-acting parts.

The advantage of the parametric switching method in series with the human body of the additional resistance is instantaneous limitation of the parameters of the defeat, and the disadvantage is not always the sufficient degree of this limitation.

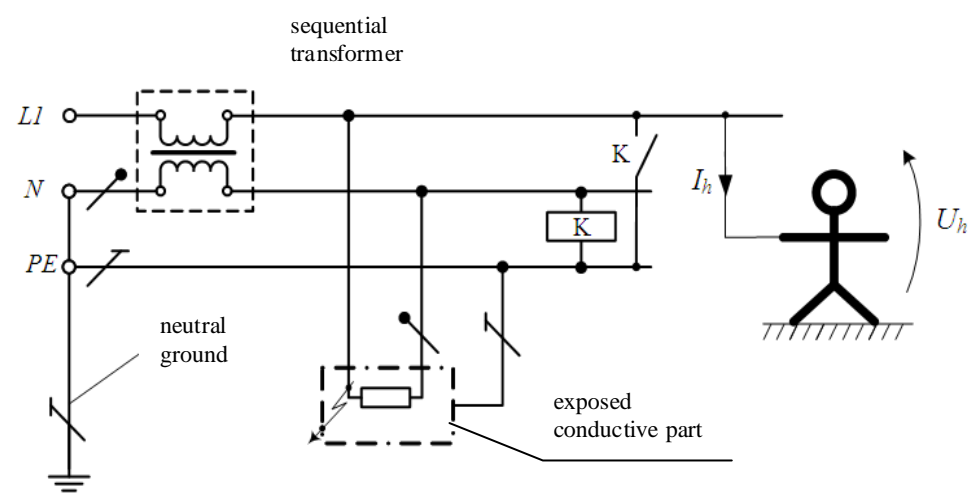

Fig.2. Scheme of a safe electricity network with a rated single-phase voltage of up to $1000 \mathrm{~V}$.

The parameters of the thyristor key should be calculated on the value of the nominal voltage of the network and the value of the current of the non-operating mode of the sequential transformer (ST) under the influence of the nominal voltage. To establish the fact of the contact of the contactor $\mathrm{K}$, it is possible to use any signal relay powered by the winding of the ST.

We will analyze a standard situation while powering residential consumers, or any other, in the case of a person coming in contact with current-carrying parts in an emergency or normal operation of an electrical installation (Fig.3).

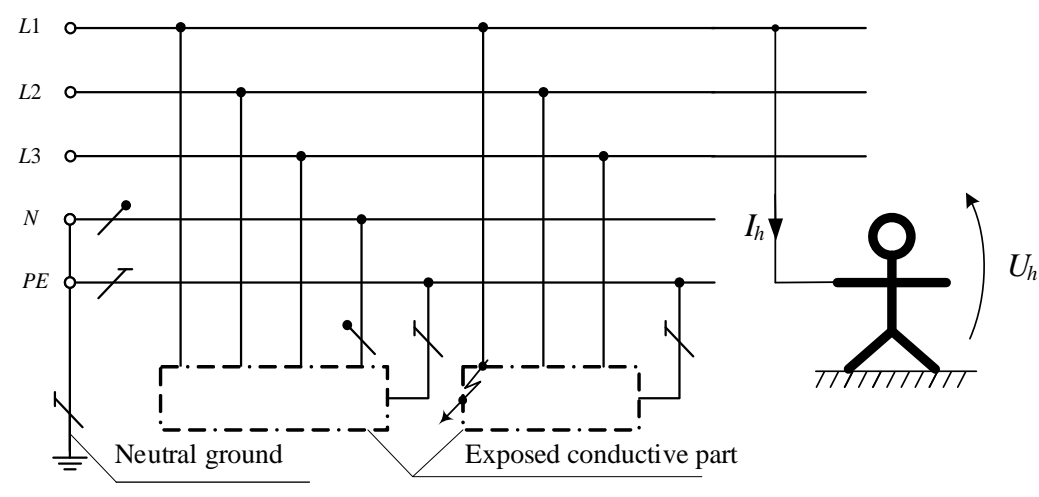

Fig.3. Scheme of a typical three-phase electricity network, rated voltage of up to $1000 \mathrm{~V}$.

Timing diagrams of voltages and currents of the power source together with the current that flows through the body are shown in Fig.4.

Fig.4,a and Fig.4,b show the diagrams of voltages at the terminals of an electrical load and a power source, respectively. The diagram of current flowing through the body is illustrated in Fig.4,d. As shown in Fig.4,c, the potential of a phase-neutral wire relative to the earth remains unaffected when touched by the person. 
a)
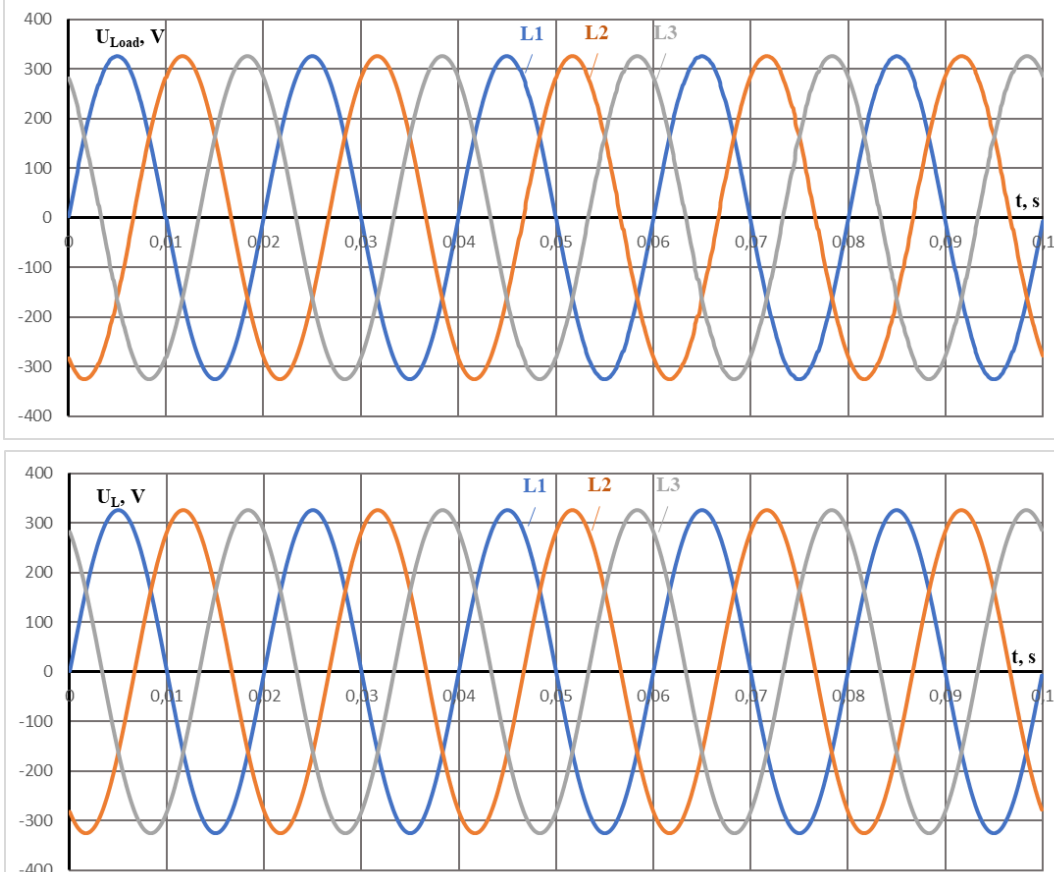

b)

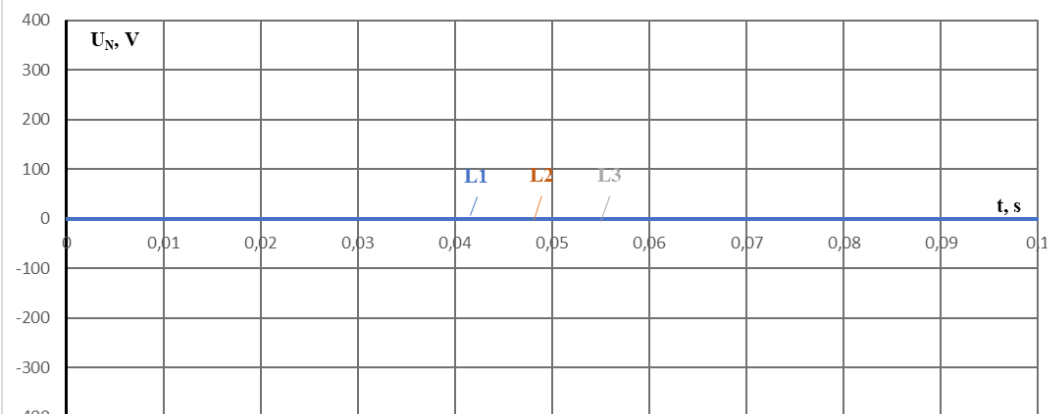

c)

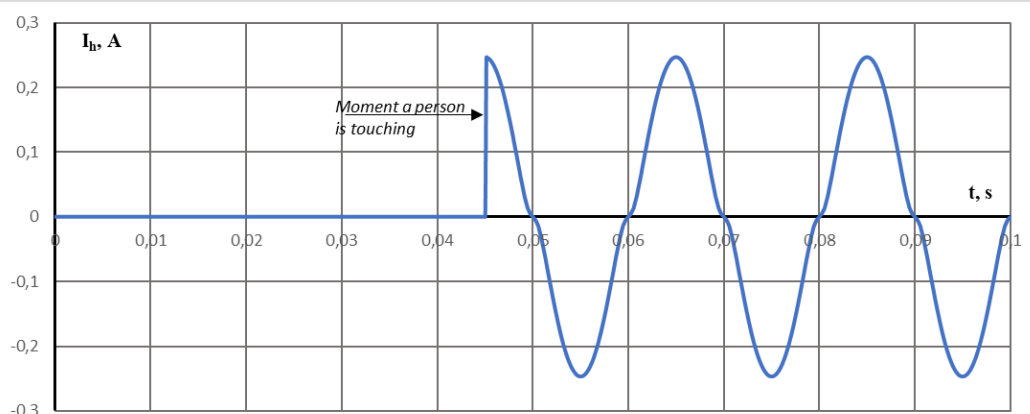

d)

Fig.4. Timing diagrams of voltages and currents of a typical electricity network in the case of a person coming in contact with elements being live.

If there is no PCB in this network, the amplitude value of the current, as illustrated by Fig.4,d, can be over $200 \mathrm{~mA}$, which is highly likely to be fatal. If the electrical circuit has the PCB, this segment of the network will be disconnected in several periods.

If the network [8] is used to supply single-phase power consumers in the three-phase network, a completely different scenario can unfold when a person gets energized (Fig.5).

In relation to the ground, the voltage on the human body after a short time period is equal to zero (Fig.5,b, the conductor L1), and the voltage value on the load will remain unchanged (Fig.5,a). However, there will be a voltage relative to the ground on the neutral conductor for the wire L1 (Fig.5,c). The value of the current flowing through the human body and its duration (Fig.5,d) will be significantly limited as compared with the current shown in Fig.4,d. 
a)

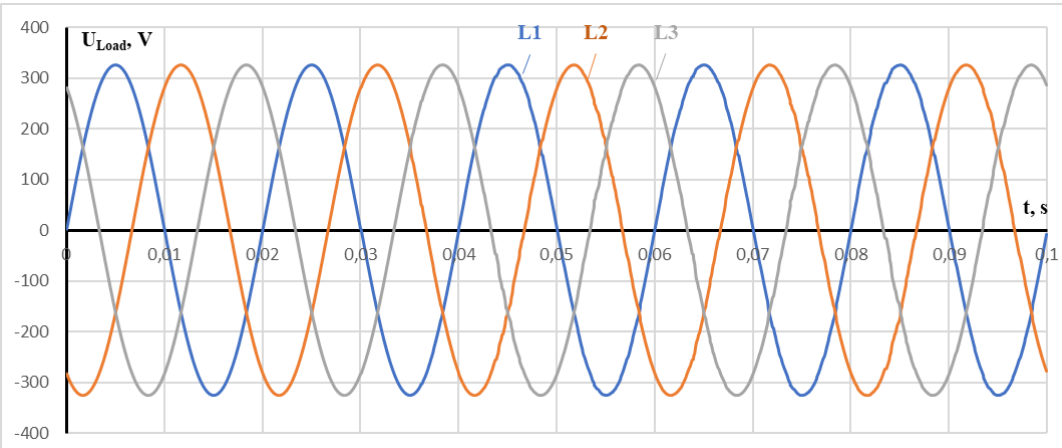

b)
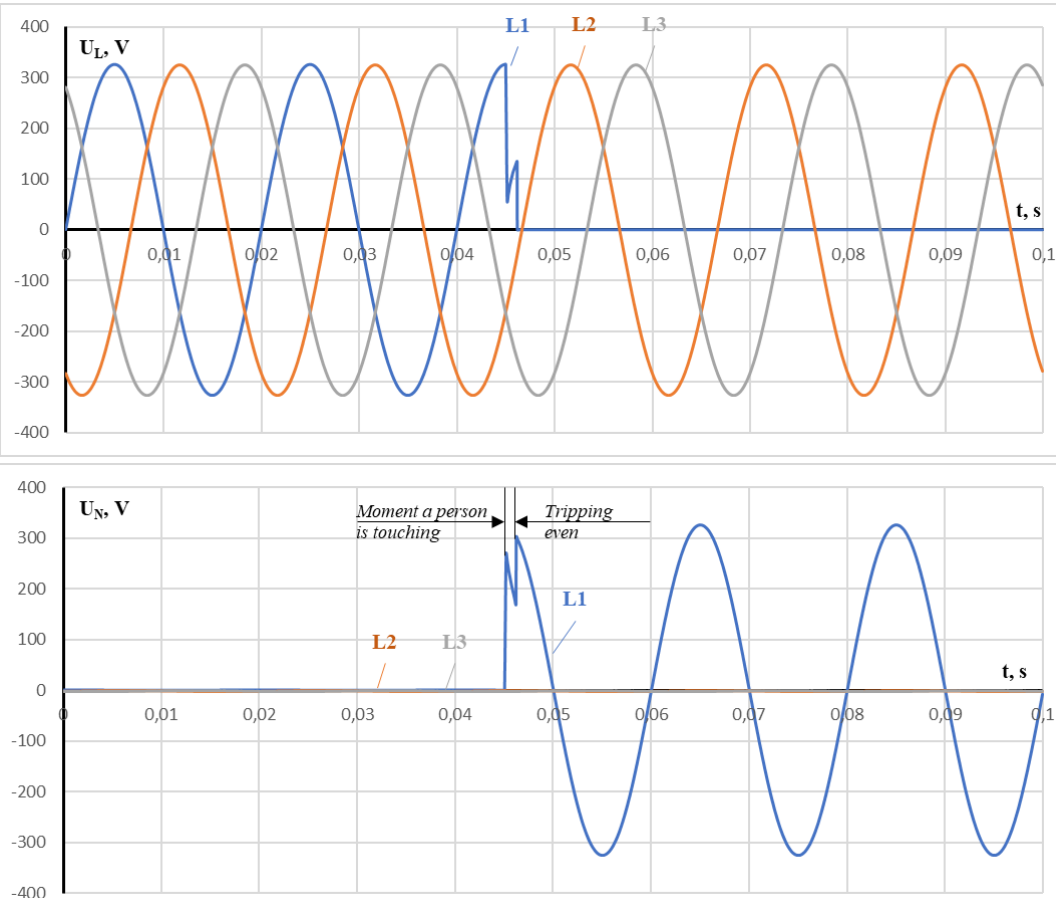

c)

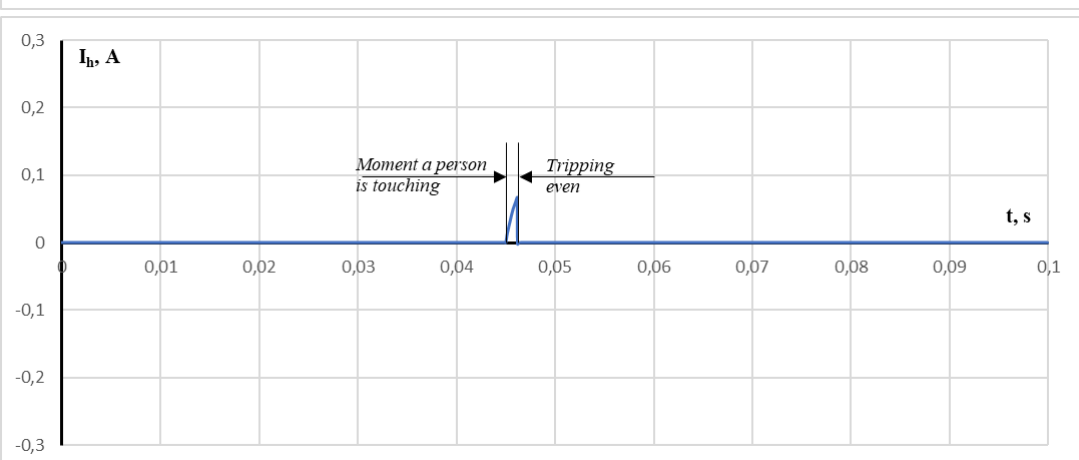

Fig.5. Timing diagrams of voltages and currents of a safe electricity network in the case of a person coming in contact with live elements.

In conclusion, besides reducing a dangerous effect of electrical energy on the human body, this network's consumers are provided with a power supply. The operating result of the safe network [9] meets certain requirements [1] provided in clause 1.2.18, i.e. "Category I current-using equipment shall be provided with electricity from two independent inter-redundant power supplies, and a power interruption due to a power outage from one of the power sources shall be accepted only for a time of automatic power recovery. Switching power supplies should be carried out in the shortest time and, if possible, without changing the operating mode of consumer equipment". It is clear that this could provoke a certain discussion, but the automatic power restoration has to be performed as soon as possible without changing the operation of the equipment of consumers (response time to $0.02 \mathrm{~s}$ ). 
In existing electrical installations, automatic power restoration owing to redundancy occurs using the automatic introduction of reservation. It can, however, take tens of periods for the actuation time. It is also possible to use automatic repeat switch-off, which is accompanied by a significant voltage-free time interval as well. Therefore, the technical solution [9], [10] can solve two problems in one operation - cause human injury or damage a phase ground wire and provide power to the electrical consumers after eliminating the consequences of an emergency situation.

\title{
3. Conclusion
}

The recommendatory nature of certain requirements for the rules and regulations are not found to result in significantly reducing electrical injuries. A crucial step to enhance electrical safety and reliability of power supply to consumers can serve as a change in approaches to the issue, but not the mere enhancement, from the technical perspective, of existing methods and techniques, technical solutions, etc.

The use of a sequential transformer in power supply circuits can practically solve the problem of limiting the voltage in emergency installations of electrical installations to acceptable values. The application of new technical solutions, which are used in the scheme of a safe electrical network, will reduce the duration of the voltage on the human body in an order of magnitude for an emergency mode of electrical installation. The presence of effective technical solutions to ensure the safety of the operation of electrical installations with a voltage of up to $1000 \mathrm{~V}$ should initiate the review of regulatory framework for electrical safety.

\section{References}

[1] Rules for electrical installations. - Official publication. Ministry of Energy and Coal Mining of Ukraine. - Kharkiv.: Fort Publishing House, 2017, 760 p. (in Ukrainian)

[2] DBN B.2.5-27-2006 "Protective measures of electrical safety in electrical installations of buildings and structures". (in Ukrainian)

[3] Records of the meeting on the issue of electrical injuries at the Ministry of Energy and Coal Mining of Ukraine, M:, November 19, 1996. (in Ukrainian)

[4] Website JSC "Prykarpattyaoblenergo". https://oe.if.ua/uk/articles/60b47b48db9c424cf6996c8f. (in Ukrainian)

[5] Malinovsky A.A., Hohulin K.B. Fundamentals of electricity and power supply: Textbook. - Second edition. - Lviv: Lviv Polytechnic National University Publishing House, 2009.- 436 p. (in Ukrainian)

[6] H. Markiewicz. Safety in the power industry. Science and Engineering Publishing (WNT). Warsaw, 2002, p. 380. (in Polish)

[7] Malinovsky A.A., Nykonets L.O., Golubov S.V., Shelekh Yu.L., Radchenko V.M., Nykonets O.L. "Scientific basis (theory) of electrical safety", Lviv: NPF "Ukrainian technologies", 2008, 224 p. (in Russian)

[8] A.Malinowski, J.Szelech, O.Nykoniec. Development of the theory of electric shock protection and synthesis of safe electric networks // XVIII Science and Engineering Conference "Electrical Safety" ELSAF-2011, Institute of Electric Power, Wroclaw University of Technology, Wroclaw, 2011. p. 24-34. (in Polish)

[9] Safe electricity network with a rated voltage of up to 1000 V. Patent of Ukraine No. 914761 Radchenko V.N., Shelekh Yu.L., Nikonets L.A. Claims dated 02.11.09: published June 26, 2010, Bulletin No. 14, 2 p. (in Ukrainian)

[10] Malinovsky A.A., Shelekh Yu.L., Nykonets O.L., Aleksandronets T.V. "Safe electricity network with a rated voltage of up to 1000 V" International scientific publication "Collection of scientific works SWorld", Ivanovo, 2013, Issure 7 "Technical sciences", pp. 34-38. (in Ukrainian)

\section{Підвищення безпеки та надійності електропостачання споживачів шляхом застосування безпечної електричної мережі напругою до 1 кВ}

\author{
Юрій Шелех $^{a}$, Мирослав Сабат $^{a}$, Владислав Лисяк ${ }^{a}$, Лідія Паращук ${ }^{b}$ \\ ${ }^{a}$ Національний університет «Львівська політехніка», вул. Степана Бандери, 12, Львів, 79013, Украӥна \\ ${ }^{b}$ Національна академія сухопутних військ імені гетьмана Петра Сагайдачного, \\ вул. Героїв Майдану, 32, Львів, 79026, Украӥна
}

\section{Анотація}

Дослідження представляють електричну мережу, яка дозволяє як підвищити рівень електробезпеки, так i усунути однофазні пошкодження електричної мережі без відключення споживача електричної енергії. Застосування мережі не вимагає значних вкладень. Продемонстровано технічну можливість впровадження електроустановки зі значеннями напруги в аварійному режимі на провідних деталях, яка не перевищує допустимих значень для нормального режиму. Додатковою перевагою пропонованого технічного рішення $\epsilon$ незмінність напруги на виводах споживача, що дозволяє йому нормально працювати в аварійному режимі електроустановки.

Ключові слова: електрична мережа; висока напруга; джерело живлення; пристрої диференційних струмів. 